\title{
The Impact of Global Warming on Aquatic Life
}

\author{
Küresel Isınmanın Sucul Yaşam Üzerine Etkisi
}

\author{
Ebru ÖZDEMIR ${ }^{1}$, Ahmet ALTINDAĞ $\breve{G}^{1}$ \\ ${ }^{1}$ Ankara University Faculty of Science Department of Biology 06100 Tandoğan, Ankara
}

\begin{abstract}
Today, almost all climatologists have agreed on that the climate change results from the increase in the greenhouse gas emissions in the atmosphere and this comes as a consequence of various human activities. The dissolution of carbon dioxide, which has the largest share among greenhouse gases in terms of contribution in global warming and climate change, in sea water is much more when compared to the other gases in the atmosphere. For this reason, oceans are large reserve resources. Since they constitute a large part of our planet and have rich biodiversity, oceans and seas are aquatic ecosystems that are affected by the process of change caused by global warming. Global warming and climate change have caused a decrease in lake waters, an increase in the sea level, and changes in streams and precipitation models and have started to show negative impacts on all aquatic organisms from plankton to mammals. Krills have decreased by $80 \%$ on average in the past 30 years. Coral bleaching have increased dramatically. The number of Indian Ocean origin fish found within the waters of our country has arrived to 30 already. Reproduction area of sea turtles have narrowed because coastal habitat to be destroyed by sea level rise. Depending on decreasing of the sea ice many of marine mammals have faced with extinction. According to the mathematical computer models developed lately, it has been calculated that in the event that the $\mathrm{CO}_{2}$ density is doubled, the global temperature will rise by $3{ }^{\circ} \mathrm{C}$. For this reason, among the precautions to be taken against global warming, decreasing of the carbon dioxide emission comes first and studies are being carried out for this purpose on an international level.
\end{abstract}

Key Words: Global Warming, greenhouse effect, carbon dioxide, biodiversity, aquatic ecosystem.

Özet: Bugün hemen hemen bütün iklim bilimciler, iklim değişikliğinin atmosferdeki sera gazı emisyonlarındaki artıştan kaynaklandığı ve bunun da insanlığın çeşitli faaliyetlerinin bir sonucu olarak ortaya çıktığı konusunda fikir birliğine varmışıı. Sera gazları içerisinde küresel ısınma ve iklim değişikliğine katkıda bulunması bakımından en büyük paya sahip olan karbondioksitin, deniz suyundaki çözünürlüğü atmosferdeki diğer gazlara oranla oldukça fazladır. Bu nedenle okyanuslar büyük rezerv kaynaklarıdır. Gezegenimizin büyük bir kısmını oluşturması ve zengin bir biyoçeşitliliğe sahip olması bakımından okyanuslar ve denizler küresel ısınmanın yaratmış olduğu değişim sürecinden en çok etkilenen sucul ekosistemlerdir. Küresel ısınma ve iklim değişikliği, göl sularında azalmaya, buzullarda erimeye, deniz seviyesinde yükselmeye, akıntılarda ve yağış modellerinde değişikliğe neden olmuş, planktondan memelilere kadar tüm sucul canlılar üzerinde olumsuz etkilerini göstermeye başlamıştır. Krillerin sayısı son otuz yıl içinde $\% 80$ oranında azalmıştır. Mercan resiflerinin beyazlaması önemli ölçüde artış göstermiştir. Ülkemiz sularında tespit edilen Hint Okyanusu kökenli balıkların sayısı şimdiden 30'a ulaşmıştır. Deniz seviyesindeki artış nedeniyle kıyı habitatı tahrip olduğu için deniz kaplumbağalarının üreme alanları daralmıştır. Birçok deniz memelisi deniz buzunun azalmasına bağlı olarak yok olma tehlikesi ile karşı karşıya kalmıştır. Son zamanlarda geliştirilen matematiksel bilgisayar modellere göre, $\mathrm{CO}_{2}$ yoğunluğunun iki katına çıkması halinde küresel sıcaklığın $3{ }^{\circ} \mathrm{C}$ artacağı hesaplanmıştır. Bu nedenle küresel ısınmaya karşı alınacak önlemlerin başında karbondioksit emisyonunun azaltılması gelmekte ve bu amaç doğrultusunda uluslar arası düzeyde çalışmalar yapılmaktadır.

Anahtar Kelimeler: Küresel ısınma, sera etkisi, karbondioksit, biyoçeşitlilik, sucul ekosistem.

\section{Introduction}

"Global warming is the process in which the earth's temperature and the temperature on the atmosphere layers that are close to earth rise artificially as a result of the intense increase in some gases that occur in consequence of various human activities and that are qualified as greenhouse gases in the atmosphere." As to global climate change, it is the phenomenon where other climatic factors change as well depending upon global warming (Anonim, 2007a).

Oceans and seas are mostly affected by the process of change caused by global warming since they constitute a large portion of our planet and have rich biodiversity. A temperature increase of only a few degrees does not only cause an increase in the temperature of large water masses such as oceans, seas, lakes, and ponds but it also causes hydrological events that cause a change in the physical and chemical characteristics of water. Water temperature is the most important environmental parameter that affects the life cycle, physiology and behaviors of aquatic living beings (Tekinay ve Güroy, 2007). Therefore, to what extent the oceans and seas will be affected by global 
warming on a worldwide scale, how global warming will affect the distribution of species, the relationship between global warming and biodiversity, and the impact of climate change on water resources which can renew themselves but are limited are topics that need to be considered carefully.

\section{Greenhouse Effect}

While the gases that are found in the atmosphere and called greenhouse gases directly permeate most of the short wave rays coming directly from the sun, they trap most of the long wave rays that are radiated back to the atmosphere after the warming of the earth. This feature of the atmosphere is called the "Natural Greenhouse Effect". A change that occurs in the rates of greenhouse gases in the atmosphere disturbs the present natural balance of the atmosphere. These results in an increase or decrease in temperature on a global basis (Anonim, 2007b).

Greenhouse gases that cause greenhouse effect are carbon dioxide, chlorofluorocarbon gases, methane, nitrous oxides, ozone, and water vapor. Their characteristics, shares in global warming and densities in the atmosphere are different from each other.

Since carbon dioxide largely permeates the short wave rays coming directly from the sun but traps the long wave rays radiated back from the earth, it is a greenhouse gas with a very important role in the warming of the lower parts of the atmosphere (Öztürk, 2002). 50-60\% of anthropogenic greenhouse effect is caused by this gas (Aksay et al., 2005). According to the mathematical computer models developed by scientists lately, it has been calculated that in the event that the $\mathrm{CO}_{2}$ density is doubled, the global temperature will rise by $3{ }^{\circ} \mathrm{C}$. This result gives an idea about how high the impact level of carbon dioxide on global warming is. Therefore, among the precautions to be taken against global warming, decreasing of the carbon dioxide emission comes first and remarkable efforts are made for this purpose on an international level (Anonim, 2007a).

Measurements taken in Hawaii as from 1958 have revealed that apart from its seasonal emissions, $\mathrm{CO}_{2}$ increases year by year as well. The graph in figure 1, called the "Keeling Curve" with reference to the name of the person performing the measurements, shows that the $\mathrm{CO}_{2}$ in the atmosphere is rapidly increasing (Anonim, 2007c).

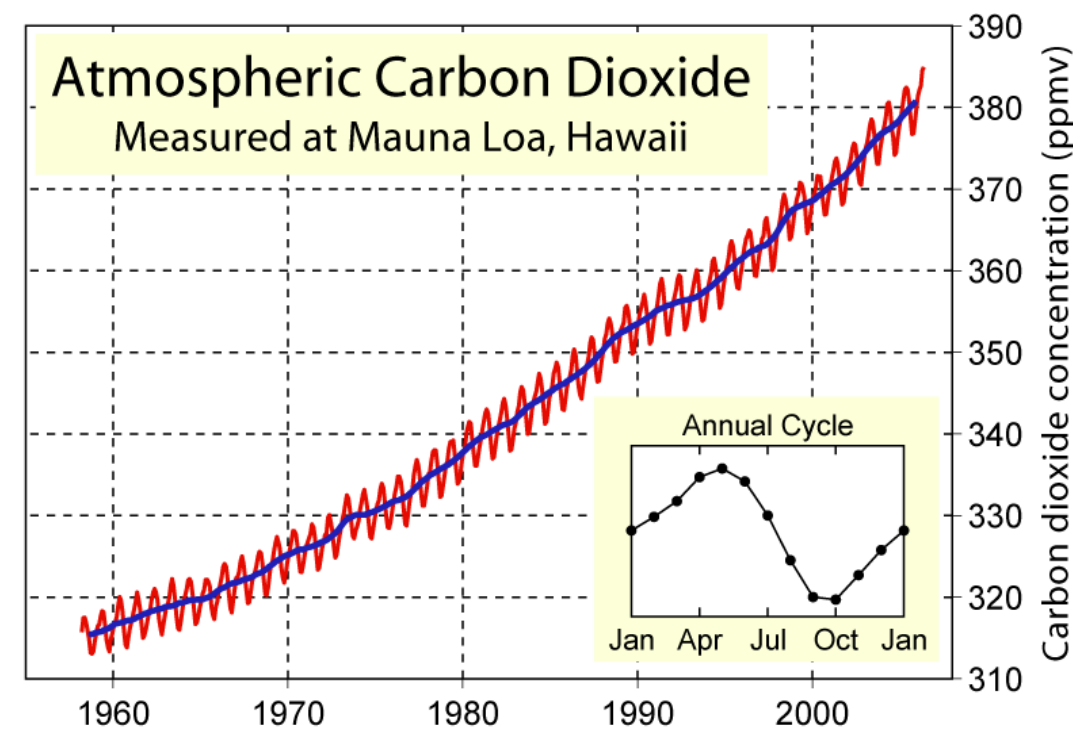

Figure 1. Increase in the carbon dioxide amount in the atmosphere by years (Anonim 2008f).

\section{The Impact of Global Warming on Aquatic Habitat}

Aquatic ecosystem is affected by the climate change through various ways. Temperature increase that occurs in the atmosphere does not only cause an increase in the temperature of large 
water masses such as oceans, seas, lakes, and ponds but it also causes hydrological events that results in a change in the physical and chemical characteristics of water (Gürer, 2007).

Climate change impacts on inland aquatic ecosystems will range from the direct effects of the rise in temperature and $\mathrm{CO}_{2}$ concentration to indirect effects through alterations in the hydrology resulting from the changes in the regional or global precipitation regimes and the melting of glaciers and ice cover (Anonymous, 2007a).

In northern latitudes, ice cover on lakes and rivers will continue to break up earlier and the ice-free periods to increase. Major changes will be likely to occur in the species composition, seasonality and production of planktonic communities and their food web interactions with consequent changes in water quality. Boreal peatlands will be affected most by and increased winter precipitation as the species composition of both plant and animal communities will change significantly. Numerous arctic lakes will dry out with a $2-3{ }^{\circ} \mathrm{C}$ temperature rise. The seasonal migration patterns and routes of many wetland species will need to change and some may be threatened with extinction. An increase or decrease in freshwater flows will also affect coastal wetlands by altering salinity, sediment inputs and nutrient loadings (Anonymus, 2007a).

Climate change can impact marine ecosystems through ocean warming, by increasing thermal stratification and reducing upwelling, sea level rise and through increases in wave height and frequency, loss of sea ice, increased risk of diseases in marine biota and decreases in the $\mathrm{pH}$ and carbonate ion concentration of the surface oceans. Theoretically, nutrient speciation could be influenced by the lower $\mathrm{pH}$ expected this century. Decreases in both upwelling and formation of deep water and increased stratification of the upper ocean will reduce the input of essential nutrients into the sunlit regions of oceans and reduce productivity. In coastal areas and margins, increased thermal stratification may lead to oxygen deficiency, loss of habitats, biodiversity and distribution of species, and impact whole ecosystems. Changes to rainfall and nutrient flux from land may exacerbate these hypoxic events (Anonymus, 2007).

The impacts that global warming has created and will probably create on aquatic ecosystem can be listed as increase in water temperature and drying of the lakes, regression of glaciers, increase in the sea level, degradation in coastal ecosystem, change in precipitation amounts and models, change in the frequency and density of extreme weather phenomena, change in streams, increase in the extinction of species and increase in the distribution areas of ailment vectors.

\subsection{Rise in Lake Temperatures and Drying of the Lakes}

The impact of global warming on lakes comes out as the increase in water temperature and regression of lakes. It is known that the Aral Sea which is among the largest lakes in the world and in Asia, Yellow River in China which is among the longest rivers in the world, Rio Grande which draws the Mexico-USA border and which is among the longest twenty rivers in the world, Owens Lake in Northern America, Chad Lake which is one of the most important lakes in Africa, Ganges River in India and Platte Lake which is one of the largest lakes in Central Europe have lost large portions of their waters due to global warming (Anonim, 2007d).

The lakes that are under threat in Turkey due to global warming are Tuz Lake, Beyşehir Lake, Eğirdir Lake, Ulubat Lake, Ereğli Reeds, Kulu Lake, Akşehir Lake, Meke Lake, Manyas Lake and Eber Lake (Anonim 2007e).

\subsection{Melting of Sea and Continent Glaciers}

Glaciers are the second largest water depositories following the oceans and the largest freshwater depositories; they constitute $98.5 \%$ of freshwater (Anonim, 2007f).

Glaciers are rapidly undergoing changes all around the world. In the $20^{\text {th }}$ century, Mount Kilimanjaro in Africa lost approximately $3 / 4$ of its glacial mass. The mass of the glaciers in Caucasus decreased by half. The glaciers on Tien-Shan mountains on the Chinese-Russian border shrank by $20 \%$ in the last 40 years. The glaciers in New Zealand lost $1 / 4$ of their masses in 20 years. The number 
of glaciers in Spain which was 27 in 1980 is 13 today. While the Qori Kalis glacier on Andes Mountains in Peru regressed 4 meters per year between 1963-1978, this regression speed reached 30 meters in 1995. Himalayan glaciers in Garhwal are melting at a great speed. Researchers believe that the glaciers in the central and western parts of Himalayas will have disappeared by 2035 (Anonim, 2007g).

Decreasing of snow due to climate changes in Southwestern Asia, particularly on Himalayas, leads to the reflection of less sun rays back to the space and increasing of the temperature on earth. The growing difference in temperature between the land and the sea strengthens the monsoon winds. And the monsoon winds that blow more strongly stir the seas and carry the nutrients to the surface and cause phytoplankton blooms (Anonim, 2007h).

Satellite data indicate that since 1978, the average annual North Pole ice size have become $2.7 \%$ smaller for each 10 years, and this value is much higher in summers; it is $7.4 \%$ for each 10 years (Abay ve Baykan, 2007).

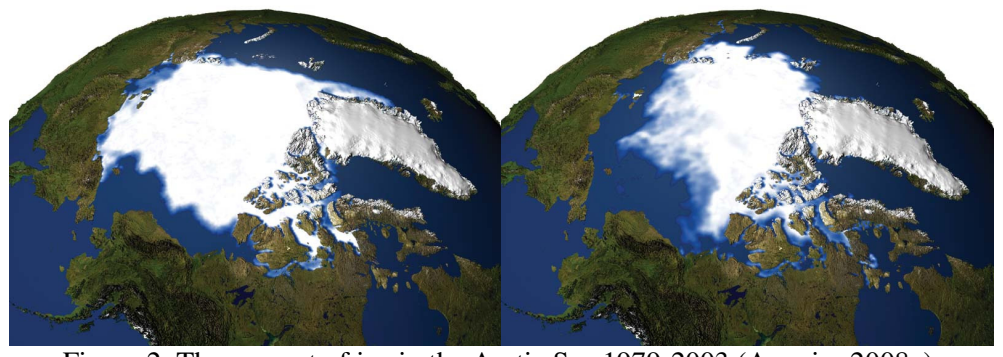

Figure 2. The amount of ice in the Arctic Sea 1979-2003 (Anonim 2008g).

\subsection{Rise in the Sea Level}

Ice melts in parallel with the increase in temperature and thus, the amount of water that flows into the seas from the glaciers and ice caps increases. The waters of oceans become warmer and their volumes expand (Anonim, 2007g). Intergovernmental Panel on Climate Change (IPCC) state that in the last century, the sea level rose by $10-20 \mathrm{~cm}$ on a global scale and this was mainly caused by global warming and that in this century, it will rise by another $40-60 \mathrm{~cm}$ (Anonim, 20071). Depending on the rise in the sea level, erosion on the coast and the coastal habitat will be seen; and as a result, the problem of salinity in freshwater reserves, change in tidal amplitude in the gulfs, chemical and microbiological pollution on the coastlines, and an increase in coastal floods will occur (Sunlu et al., 2001).

\subsection{Degradation in the Coastal Ecosystem}

The main impact of global warming and climate change will be seen on coasts, the most productive areas of seas (Anonim, 20071). Experts conducting studies on coasts have calculated that each rise of one $\mathrm{cm}$ in the sea level may cause a horizontal regression with a width of $1 \mathrm{~m}$ on sandy coastal lines due to erosion (Anonim, 2007g).

The changes in the sea water level will endanger the coastal habitat and species such as the sea turtle which uses the beaches as reproduction areas and lays eggs there will be unfavorably affected since their reproduction areas will become narrower (Anonim, 20071).

\subsection{Change in Precipitation Amounts and Models}

The changes to be seen in the seasons and in yearly precipitation bear importance in terms of both storing water resources and the regulation of the humidity regime in the soil (Öztürk, 2002).

In regions that receive a great deal of precipitation, the flow rates of streams will gain speed due to impetuous precipitation; and in regions that receive little precipitation, evaporation will be fast due to drought and there will be a decrease in the amount of usable water (Anonim, 2007i). 


\subsection{Change in the Frequency and Density of Weather Phenomena}

The changes in the frequency and density of weather phenomena will influence ocean currents. The growing difference in temperature between the land and the sea will strengthen the monsoon winds. And the monsoon winds that blow more strongly will stir the seas and carry the nutrients to the surface and cause phytoplankton blooms (Anonim, 2007h).

\subsection{Change in Currents}

In the oceans, there are large currents that are active. These currents have remarkable impacts on water cycle and weather conditions. The differences that occur in the sea water density depending on the salinity rate and temperature of the water, and the winds and storms cause currents. As a result, cold water currents such as Humboldt and hot water currents such as Gulf Stream occur and these affect the surrounding climate conditions (Anonim, 2008a).

The researches have put forward that the glaciers in the North Pole will melt due to global warming and that the glaciers that will have melt may completely stop the Gulf Stream hot water current in 10 years. The complete discontinuation of the flow of the Gulf Stream may take the world to a point of no return. It may cause the northern hemisphere of the earth to begin a new glacial era since Gulf Stream reaches Northern Europe from Mexican Gulf over the Atlantic Ocean and makes the climates of England, Ireland, northern parts of France, Belgium, the Netherlands and Germany become temperate. Besides, the plankton carried through the ocean with the effect of Gulf Stream, that is, the first links of the food chain, will have disappeared and all the food links, mainly the fish that feed on these plankton, will suffer. Extinction of these living beings will result in the starvation of the living beings feeding on them, and this will affect the humans, an important link of the food chain (Anonim, 2005).

\subsection{Increase in the Distribution Areas of Vectors}

As a result of the warming of sea water, the number of bacteria living in high temperature and their disease causing capacities will increase more. For this reason, global warming poses danger for fish breeding performed in seas (Anonim, 20071).

What is known is that most coral diseases occur at higher-than-normal sea-water temperatures. As temperatures are expected to rise considerably during the next few decades, it is likely that coral diseases will become more prevalent (Rosenber and Ben-Haim, 2002).

The models predict that in the event of an increase by 3-5 degrees in the earth's temperature until 2100 , malaria prevalence will affect $45-60 \%$ of the world's population until the second half of the next century. This implies a patient increase of 50-80 million per year. An increase in diseases such as salmonellosis and cholera is also expected as a result of high temperature and floods (Anonim, 2006a).

\subsection{Increase in the Extinction of Species}

Since the breaking of the nourishment chain in nature once will lead to incredible results, the extinction of some species will directly affect the other species (Anonim, 2006b).

In the 2007 report of Intergovernmental Panel of Climate Change, it is stated that if the average temperature of the earth increases by $1-2{ }^{\circ} \mathrm{C}$, one third of the species on the earth will change their distribution areas or become extinct (Anonim, 2007j).

\section{The Impact of Global Warming on Aquatic Organisms}

\subsection{Plankton}

Along with global warming, precipitation regime will change due to changing atmospherical rhythm, nourishing loads will suddenly enter the sea, and thus, seasonal plankton blooms will be probable. As the case is today, with the accumulation of organic materials that reproduce more than 
they are consumed on the bottom and their degrading the marine sulfates to sulfurs, living beings' life will be trapped in a narrow zone (Anonim, 20071).

Fish such as anchovy (Engraulis encrasicholus) and sprat (Sprattus sprattus) feed on plankton and makes the absorption of organic loads in the water colony possible. In a process where this does not happen, that is, where the plankton drift on the bottom, $\mathrm{H}_{2} \mathrm{~S}$ formation on the bottom will speed up and thus, with the decreasing of fish consuming organic materials in the system, $\mathrm{H}_{2} \mathrm{~S}$ layer will rise even more (Anonim, 20071).

\subsection{Crustaceans}

The increase in the $\mathrm{CO}_{2}$ amount which is among the causes of climate change results in the decline of sea water's $\mathrm{pH}$, and thus the acidification of the sea water. This case negatively affects the crustaceans. The outer skeletons of crustaceans consist of aragonite, a common form of calcium carbonate, and it can dissolve in acidic sea water. Extinction of these small crustaceans found at the bottom of the nutrition chain can change the entire sea ecosystem (Anonim, 2006c).

Another negative impact that climate change has caused on crustaceans comes out with the regression of sea ice. Oceanographists point out that small crustaceans that are called krill and that feed on phytoplankton have decreased by $80 \%$ on average in the past 30 years. They attribute this case to the decreasing of the ice cover carried by South Ocean in winter since winter ice is of great importance for the life cycle of algae and krill feed on algae. Extinction of krill that are the nutrition resource for many sea mammals and living beings in the sea may mean the destruction of the food chain in the South Ocean (Anonim, 2008b).

\subsection{Coral Reefs}

Coral reefs are very important for oceans as these reefs are the places where the carbon cycle takes place. Coral reefs constitute a natural set against big ocean waves and tidal waves and serve for the protection of coastal lines. The fish and other crustaceans they hold are a significant source of food and mainstay. Reefs are places where many large living beings come to reproduce. Fish that are densely caught by humans either reproduce at these reefs or use the food produced by these reefs. If we consider that these form a chain in the shape of a pyramid, the destruction of the order in the reefs means the destruction of this chain (Anonim, 2008c).

Tropical coral reefs are increasingly threatened by shifts in the world's climate, overfishing and declining water quality. High levels of genetic diversity within populations of corals are likely to be an important element in evolutionary responses to climate change. Populations at high latitudes may be more vulnerable to climate change because they are typically at the margins of geographical ranges, and are likely to be small and isolated (Ayre and Hughes, 2004).

Corals grow as long as they are not broken because of external influences. However, the changes in the temperature and acidity rates kill and solidify the corals. The dead corals that are white-gray in color can not grow any more (Anonim, 2008c). For instance, in Caribbean in 19891990, the increase in the temperature of the sea water by two degrees, that is, rising of the water temperature to $30-31{ }^{\circ} \mathrm{C}$ from $28-29{ }^{\circ} \mathrm{C}$, have caused mass death of corals. In fact, extinction of corals does not only lead to the destruction of biodiversity in the seas, but it also causes a decrease in the absorption of $\mathrm{CO}_{2}$, which is responsible for global warming at the first rank, by the seas. Such processes are interpreted as the sign of the global collapse of the system by the experts (Anonim, 20071).

\subsection{Fish}

Water temperature comes the first in the list of most determinant factors since it is essential for the reproduction of fish species and the formation of an ideal living environment. In preadolescence stages called larva and juvenile, fish are quite susceptive to changes in the water temperature (Anonim, 20071). 
A fish population can be tolerant of temperature changes in the area where it is distributed in a certain time interval. If these changes are within a certain temperature boundary and slow, it generally causes migration of fish. Temperature takes important physiological phenomena such as feeding, respiration, osmoregulation, growth and reproduction under control. If the individuals of population can not adjust themselves according to the sudden and strong changes in temperature, one or some of their metabolism activities may deteriorate and mass deaths may occur (Avşar, 2005).

If long term temperature increases are observed in a region, in any stock that is prevalent in that area, shifting of the southern border of the ovulation area towards the north, changing of ovulation areas horizontally with any increase in the bottom water temperature, preference of northern latitudes as new areas of feeding and growth, increase in food salts and amounts with the increase in temperature on higher latitudes and changes in the present currents, prolongation of the growth period in a year, and shifting of the limit within which larvae may live towards northern latitudes may be observed (Avşar, 2005). For instance, that the fish of Thallossoma pavo species can now be observed in the Sea of Marmara and that its distribution has shifted towards the north from the south of the Mediterranean Sea is explained with the impacts of global warming (Anonim, 20071).

The number of Indian Ocean-origin fish found within the waters of our country is more than 30 already. One of the main reasons for the entrance of all these species into eastern Mediterranean and their competition for areas with local species is the increase in water temperature in the Mediterranean (Anonim, 20071).

The hot lower current with high salinity from the Mediterranean to the Black Sea and the cold upper current with low salinity from the Black Sea regulate the distribution and migration of living beings in the sea. The increase in the sea water temperature affects the transition and entrance of thermophilic fish species into the Black Sea. Fish such as Sardinella aurita, Boops boops, and Sarpa salpa living in the Mediterranean were very rarely seen in the Black Sea and the Marmara 20 years ago. Today, they are frequently observed in those seas and even caught in the Western Black Sea, and this is attributed to the increase in the sea water temperature (Anonim, 20071).

Another effect of climate change is the decrease in the $\mathrm{pH}$ level of the sea water through increasing atmospherical $\mathrm{CO}_{2}$. In a study they conducted on Cyprinus carpio, Çalta and Ural (2001) researched into the effects of high and low $\mathrm{pH}$ on spawns and larva, and they observed that $99 \%$ of the hatching of eggs in the high $\mathrm{pH}$ level environment while $39.5 \%$ of the hatching of eggs in the low $\mathrm{pH}$ level environment; and that $85 \%$ of the spawns bore normal juveniles in the high $\mathrm{pH}$ level environment while only $1.2 \%$ of the spawns bore normal juveniles in the low $\mathrm{pH}$ level environment (Çalta ve Ural, 2001).

\subsection{Turtles}

Another living being that is under threat due to global warming is the turtles. For the majority of living beings, the sex of the juveniles are determined by the chromosomes, however, in some living beings such as the tortoises, the environmental conditions determine whether the juvenile will be male or female. Among the environmental factors that affect physiological characteristics such as the sex rates of the juveniles, incubation period, the process of building a nest, growth, activity and winter sleep, the most determinant factor is the temperature of the habitat. For species the juvenile's sex of which is determined by the habitat temperature during incubation period, male juveniles are formed in lower temperatures $\left(20-27{ }^{\circ} \mathrm{C}\right)$, and female juveniles are formed in temperatures higher than $30{ }^{\circ} \mathrm{C}$; and between $28-31{ }^{\circ} \mathrm{C}$ the juvenile may be either male or female. As for the lizards and alligators, the juveniles coming out of the egg in high temperatures are male and the ones that come out in low temperatures are female. For this reason, reptiles, particularly turtles and alligators, are among the species that will perhaps be most drastically influenced by global warming. The increase in temperature will distort the sex rate in future generations and probably cause the emergence of groups of only females in turtles and only males in alligators that will definitely not be able to continue breeding. In a study carried out in the USA, it was presented that an increase of $1{ }^{\circ} \mathrm{C}$ in the 
habitat temperature caused nearly all the juvenile turtles to be females. The digestion, growth rates, activities and reproduction rates of animals such as alligators and turtles are also affected negatively by the increase in temperature (Anonim, 2008d).

\subsection{Marine Mammals}

Climate change is now known to be affecting the oceans. It is widely anticipated that impacts on marine mammals will be mediated primarily via changes in prey distribution and abundance and that the more mobile (or otherwise adaptable) species may be able to respond to this to some extent. However, the extent of this adaptability is largely unknown. Meanwhile, within the last few years direct observations have been made of several marine mammal populations that illustrate reactions to

climate change. These observations indicate that certain species and populations may be especially vulnerable, including those with a limited habitat range, such as the vaquita Phocoena sinus, or those for which sea ice provides an important part of their habitat, such as narwhals Monodon monoceros, bowhead Balaena mysticetus and beluga Delphinapterus leucas whales and polar bears Ursus maritimus (Simond and Isaac, 2007).

Polar bears are among the living beings that will be mostly affected by the decrease in the sea ice. The decreasing of the sea ice, which allows them to feed at remote distances, due to global warming will cause the polar bears not to feed properly. Polar bears can still carry on their lives like that, but the fat rate in their bodies will decrease because of malnutrition. This case means extinction for polar bears which require a certain amount of fat rate in their bodies to reproduce.

In the next 50-100 years, a significant decrease in sea glaciers is expected due to global temperature change. As a result of habitat loss and decreasing of the habitat quality, a decrease of $30 \%$ is estimated in the polar bear population (Anonim, 2008e).

\section{Conclusion}

Global warming and climate change which have caused the ecological systems, biodiversity and human life to confront the biggest problem of history have started to show their impacts on all living beings in the aquatic ecosystem from plankton to mammals.

The studies that have been conducted indicate that the deterioration in the climate caused by global warming will continue to the future even if precautions are taken today. Just as the climate changes that we observe today are the results of phenomena that have piled up through years, the effects of the precautions to be taken that may be considered positive will require nearly the same amount of time. Since we do not have the chance to reverse the global warming and climate change phenomena, the only thing that needs to be done is to minimize the foreseen harms in the future. To this end, mankind needs to understand the global warming problem and cooperate on an international level.

\section{References}

Abay, O. ve Baykan, N.O. 2007. İklim değişikliği görüşlerindeki gelişmeler. I. Türkiye İklim Değişikliği Kongresi, Bildiriler Kitabı: 154-160. 11-13 Nisan 2007, İstanbul.

Aksay, C. S., Ketenoğlu, O. ve Kurt, L. 2005. Küresel 1sınma ve iklim değişikliği. SÜ, Fen-Ed. Fak, Fen Dergisi, 25: 29-41.

Anonim 2005. Çok alametler belirdi. http://arsiv.sabah.com.tr/2005/04/05/gnd102.html.

Anonim 2006a. Yeni yüzy1l felaketlerle gelecek. http://teknoloji.milliyet.com.tr/detay.asp?id=1443.

Anonim 2006b. Küresel isınmanın etkileri nedir? http://www.bey.tcb.org/bcb_ki_etkileri_nedir.htm.

Anonim 2006c. Denizlerin asit oranı giderek artıyor. http://www.geodergi.com.tr

Anonim 2007a. Kürsel 1sınma ve küresel iklim değişimi. http://www.tema.org.tr/CevreKutuphanesi/KureselIsinma/pdf/KureselIsinma.pdf.

Anonim 2007b. Küresel iklim değişimi ve küresel 1sınma. http://www.iklim.cevreorman.gov.tr/Gazi/makale_sengun.htm. 
Anonim 2007c. İklim değiş̧ikliği.

http://www.cevreciyiz.com/akademi/yazilar_detay.aspx?SectionId=168\&ContentId=129.

Anonim 2007d. Hayat havadan sudan geçiyor.

http://hurarsiv.hurriyet.com.tr/goster/haber.aspx?id=7771556.

Anonim 2007e. Göllerimiz yok oldu. http://arama.hurriyet.com.tr/arsivnews.aspx?id=7532797.

Anonim 2007f. Buzul. http://tr.wikipedia.org/wiki/Buzul.

Anonim 2007g. Küresel isınma. http://www.yaklasansaat.com/dunyamiz/kuresel_isinma/eko.asp.

Anonim 2007h. İklim bilmecesi. http://ocean.mit.edu/ imarinov/AtlasMagazine.pdf.

Anonim 20071. Küresel Isınma ve Türkiye Denizleri Raporu. Türk Deniz Araştırmaları Vakfı Yayını, İzmir.

Anonim 2007i. İklim değiş̧ikliğinin su kaynakları üzerine etkileri. http://cevre.club.fatih.edu.tr/webyeni/konfreweb/konu4.pdf.

Anonim 2007j. Küresel ısınmanın etkisi ortaya çıkıyor. http://hurarsiv.hurriyet.com.tr/goster/haber.aspx?id=6234501\&tarih=2007-03-30.

Anonim 2008a. Isınıyoruz. http://www.haberbilgi.com/bilim/cevre/kuresel_isinma02.html.

Anonim 2008b. Küresel 1sınma ve sonuçları. http://www.haberlerimiz.com/yazaryazi.asp?idyazar=24\&idyazi=489.

Anonim, 2008c. Mercan resifleri. http://antrak.org.tr/index.php?option=com_content\&task=view\&id=78\&Itemid=27 .

Anonim 2008d. Kaplumbağa ve timsahlar tehlikede. http://www.gencbilim.com/news/science_news.php?id=2616.

Anonim 2008e. Kutup ayıs1. http://tr.wikipedia.org/wiki/Kutup_ay\%C4\%B1s\%C4\%B1

Anonim 2008f. http://en.wikipedia.org/wiki/Carbon_dioxide

Anonim2008 g. http://www.indigodergisi.com/_derived/didem_02_17.htm_txt_artic_1979.gif

Anonymus 2007. Working Group II Report "Impacts, Adaptation and Vulnerability": Intergovernmental Panel on Climate Change (IPCC), Switzerland.

Avşar, D. 2005. Balıkçılık Biyolojisi ve Populasyon Dinamiği. Nobel Kitabevi Yayınları: 332, Adana.

Ayre, D. J. and Hughes, T. P. 2004. Climate change, genotypic diversity and gene flow in reef building corals. Ecology Letters 7: 273-278.

Çalta, M. ve Ural, M. Ş. 2001. Aynalı Sazan (Cyprinus carpio L., 1758) yumurtalarının açılması ve larvaların yaşama oranı üzerine suyun $\mathrm{pH}$ değerinin etkisi. E.Ü. Su Ürünleri Dergisi 18 (3-4): $319-324$.

Gürer, İ. 2007. Küresel ısınma, Türkiye'nin su kaynakları, olası etkileşim. I. Türkiye İklim Değişikliği Kongresi, Bildiriler Kitabi: 8-27. 11-13 Nisan 2007, İstanbul.

Öztürk, K. 2002. Küresel iklim değişikliği ve Türkiye'ye olası etkileri. G.Ü. Gazi Eğitim Fakültesi Dergisi 22 (1): 47-65.

Rosenberg, E. and Ben-Haim, Y. 2002. Microbial diseases of corals and global warming. Environmental Microbiology 4 (6): 318-326.

Simond, M. P. and Isaac, S. T. 2007. The impact of climate change on marine mammals: early signs of significant problems. Oryx 41 (1): 19-26.

Sunlu, U., Kaymakçı A. ve İzgören, F. S. 2007. Denizlerde karbon dinamiği. E.Ü. Su Ürünleri Dergisi. 18 (1-2): 233-241.

Tekinay, A. ve Güroy, D. 2007. İklim değiş̧ikliği Türkiye balık üretimini nasıl etkileyecek? I.Türkiye İklim Değişikliği Kongresi, Bildiriler Kitabı: 329-334. 11-13 Nisan 2007, İstanbul. 